\title{
Post-disaster Policy Decision Making and the Prospects of Human Rights --- The Case of Fukushima Daiichi Nuclear Power Plant Accident
}

\author{
Khadija Javed Khan \\ Independent Consultant, Development Evaluation and Human Rights, Vienna, Austria
}

Copyright $\bigcirc 2018$ by authors, all rights reserved. Authors agree that this article remains permanently open access under the terms of the Creative Commons Attribution License 4.0 International License

\begin{abstract}
The day of 11 March 2011 will be sadly remembered in the history of the rise and rise of nuclear power since its discovery a couple of centuries ago due to Fukushima Daiichi Power Plant accident, the third in the series of colossal nuclear accidents after 'Three Mile Island' (USA) and 'Chernobyl' (Ukraine, former Soviet Union). Each of these accidents reminded the international community of the risk inherent in nuclear technology, however, the demand for the so called clean energy and assertive approach of nuclear industry continued to push forward proliferation of technology in power generation. Five years down the line and despite government efforts to normalize the situation, the apprehensions about Fukushima evacuees' resettlement, economic uplift, political stability, governance and fulfillment of human rights including health consequences of radiation from Fukushima fall out on the affected population and workers, still linger on. This paper provides an account of post-disaster multi-faceted issues and challenges that came in the wake of disaster during the period 2011-2016 as seen through the lens of media and assessed in the prospects of human rights. The policy analysis is framed within the scope of the UN 'Bill of Rights' in four thematic areas: natural/fundamental rights and liberties, political and socio-economic perspective, development, technological and environmental perspective, and governance and legal perspective.
\end{abstract}

Keywords Fukushima Daiichi Power Plant, Nuclear Accident, Radiation Risk, Radiation Protection, Evacuees, Policy Decision Making, Governance, Public Trust, Human Rights, The UN Bill of Rights

\section{Introduction}

During the last fifty years a number of nuclear accidents
[1] occurred across the globe; three of them made a lasting impact on the life and perception of people about the production and the use of nuclear energy. These are: Three Mile Island (Pennsylvania, USA) accident in 1979, Chernobyl (Ukraine, former USSR/present Ukraine) disaster in 1986 and Fukushima Daiichi Power Plant (Fukushima, Japan) melt down in 2011. Each of these accidents reminded the international community of the risk inherent in nuclear technology, however, the demand for the so called clean energy and assertive approach of nuclear industry continued to push forward proliferation of nuclear technology in power generation.

Once, a policy decision is made to include nuclear power in the energy portfolio, the pragmatic way forward is to make it safe for the public both in normal conditions and in emergencies. Most of all, to keep the public informed of the radiation risk in case of accidents, thus, the enhanced role of policy makers and scientists as social actors and communicators to be considered as an essential part of their professional training [2] and responsibility.

\section{- Significance of the Study}

The discourse on post-disaster decision making from human rights standpoint is a new theme with limited scope for expansion, dissemination and intervention due to its political sensitivity. There exists brief but highly valuable literature on humanitarian and ethical issues in nuclear post-disaster scenario, particularly related to Chernobyl disaster. It provides an entry point for human rights advocates to extend the discussion to human rights issues touching the lives of affected population in the aftermath of Fukushima Daiichi Nuclear Power Plant accident. The study, despite its limitations, aims to invoke interest among the academic and human rights circles to support future research efforts in this area for developing a better understanding of the application of human rights in post-disaster policy making in the light of international/UN 
conventions.

\section{- Validity}

The validity of the research was assured by using a process-based methodology of content analysis of the text from selected sources of information and complemented with literature review. It included ten key steps undertaken to conduct research, qualitative analysis and discussion as explained below under the section on methodology. The two international media sources were selected. One print 'The Economist' and the other electronic 'The Time Magazine Newsfeed' published over a period of 5 years from March 2011 to March 2016 with comprehensive coverage of unfolding events in post-Fukushima Japan year after year. The human rights based approach was applied to develop an analytical framework. The selected articles and newsfeed items were screened to extract relevant information/text which was organized under four specific categories covering a broad spectrum of life as follows:

- Natural/Fundamental Rights and Liberties

- Political and Socio-Economic perspective

- Development, Technological and Environmental perspective

- Governance and Legal perspective

The information was analyzed for policy decisions and direction. The human rights debate was generated within the scope of international/UN conventions.

\section{- $\quad$ Reliability}

The study is based on a body of information (the Corpus), consisted of two English Language media sources 'The Economist' and 'The Time Magazine Newsfeed' as well as various articles from other prestigious political, economic, social and scientific magazines and journals published during and after Fukushima disaster. All the articles and newsfeed items are placed on record so that the statements quoted in the study can be traced back to their origin. One major source of scientific and technical information is 'The Fukushima Daiichi Accident Report by the Director General, International Atomic Energy Agency (IAEA) GC (59)/14, 2015'. All references are provided at the end of the research paper.

\subsection{The Case of Fukushima Daiichi Nuclear Power Plant}

In the policy discourse on Fukushima disaster, the case of Daiichi Nuclear Power Plant plays a central role in understanding the success and failure of a governance system in the decision making process. The Guardian called it 'one of the defining events of our age' [3].

Fukushima Daiichi Nuclear Power Plant is located on a $3.5 \mathrm{sq} \mathrm{km}$ site covering the towns of Okuma and Futaba within Fukushima Prefecture. The plant was commissioned in 1971. It consisted of six light water reactors and was considered the world's 15th largest facility in terms of generating electricity to $4.7 \mathrm{GWe}$ i.e. 4.7 billion electric watts [4]. As reported in 'The Economist', the magnitude-9 earthquake that hit Japan in the wake of a powerful tsunami was 'the largest ever in the country's history, equivalent in power to 30,000 Hiroshimas' [5]. The devastation was shocking for the whole world. It was reported at that time that 5,429 lives were lost [6]. There was a warning that 'those calculations could change dramatically if the nuclear crisis worsens' [7]. Rightly so; a recent article in the Time Magazine puts the death toll to almost 3 times higher i.e. 15,893 and the number of missing people at 2572 [8]. The tsunami and the earthquake together caused the destruction of 127,290 buildings and damaged around a million.

The power outage at Fukushima Daiichi Nuclear Power Plant and the failure of cooling system consequently heated up the plant and caused meltdown of the nuclear core. Concerned with the risk of radiation leak, the authorities organized evacuation of 150,000 residents from within 20 kilometres of the power plant to safer place [9].

The nuclear fall-out exposed a number of shortcomings in the nuclear power plant technology, its management and the overall governance system. Besides the loss of human lives (although not directly due to the nuclear accident) and physical and economic assets, the reputation of the responsible entities including the government, the power company TEPCO and the national and international regulatory authorities was put at stake.

From an assessment of the way the Fukushima Nuclear Power Plant accident unfolded, it could be called a 'Killer Risk'[10], in which 'events presenting an unfavourable combination of circumstances leading to hazard or major loss or damage results in permanent cessation of operations' [11]. 'Although a radiation disaster is quite rare, its effects will be devastating not only for the individuals but also for the whole society and the nation' and therefore '(p)roper understanding of radiation is fundamental to saving the lives of victims as well as maintaining the effects of radiation on rescuers' [12].

The crisis is not yet over as the nuclear authorities in Japan are preparing to deal with the threat of on-going radioactive releases for the next forty years. Besides, the power company TEPCO is facing accountability for 'professional negligence' [13].

We are going to have a closer look at the aftermath of the disaster and a series of policy decisions taken over a period of five years (March 2011- March 2016) from a different perspective. We wear the lenses of human rights to study and analyze the policy issues in order to raise the level of consciousness about the Bills of Rights as a means to good governance aimed at protecting people from exposure to personal, mental, physical and material harm in post-disaster situations. 


\subsection{The Bill of Rights and its Relevance to Post-disaster Decision Making}

The global community through its representatives at the United Nations General Assembly (UNGA) adopted a number of human rights conventions during the last 70 years which made a significant contribution to the state of human rights and humanitarian affairs, and served the nations in bringing peace and equality among people living in an unequal world. Three core human rights conventions that form the Bill of Rights include the Universal Declaration of Human Rights (UDHR), International Covenant on Civil and Political Rights (ICCPR) and International Covenant on Economic, Social and Cultural Rights (ICESCR). Other core conventions are focused on marginalized groups such as the women, children, refugees, migrant workers and people in prisons [14]. There are many other relevant legal instruments, three of which are worth mentioning in the context of Fukushima disaster:

- European Convention on Human Rights/Convention for the Protection of Human Rights and Fundamental Freedoms, Rome, 4.XI.1950

- International Labour Organization (ILO) Convention 155 on Occupational Safety and Health (OSH), 1981

- IAEA Basic Safety Standards (BSS) - for protecting workers, public and environment from radiation

The above ILO and IAEA instruments, their protocols, and the safety standards contained in them have continuously been aligned to emerging needs; the latest changes in the OSH and BSS are expected after Fukushima accident.

A short list of conventions is provided in Annex 1.

The Human Rights conventions provide a broad framework to cover fundamental human rights and liberties both in normal conditions and during emergencies, also included in Geneva Convention. The human rights value system is described as the "biggest achievement of the Age of Enlightenment in Europe and with it the rationalistic doctrine of natural law was to recognize individual human beings as subjects endowed with rights against the society and to place them at the centre of legal and social systems' [15].

The State parties signatory to the Universal Declaration of Human Rights (and/or other UN Human Rights conventions) are responsible to respect, fulfill and protect the natural rights of the individual such as the rights to life, liberty, property, security and happiness [16], and other specific rights such as civil, political, social, economic and cultural rights.

The concept of human rights application across various phases of post-disaster management is aimed at protecting the affected population from exposure to any social, economic, physical, mental and psychological harm, and to maintaining dignity of life during evacuation and transitional living in camps till return to normal conditions. What is construed by various phases of disaster management? According to the United States, Federal Emergency Management Agency [17], there are four phases of emergency (disaster) management as follows:

(1) Mitigation - the application of measures that will either prevent the onset of a disaster or reduce the impact should one occur;

(2) Preparedness - preparedness activities prepare the community to respond when a disaster does occur;

(3) Response - the employment of resources and emergency procedures as guided by plans to preserve life, property, the environment, and the social, economic, and political structure of the community, during the onset, impact, and immediate restoration of critical services in the aftermath of a disaster;

(4) Recovery actions taken in the long term after the immediate impact of the disaster has passed to stabilize a community and to restore some semblance of normalcy.

The definition of phase (3) i.e. response to the disaster fully corresponds with the comprehensive human rights framework that we have prepared to serve the objectives of this study in four thematic categories as follows:

- Natural/Fundamental Rights and Liberties

- Political and Socio-Economic perspective

- Development, Technological and Environmental perspective

- Governance and Legal perspective

\section{Research Design and Methodology}

The methodological process consisted of ten key steps as defined in Figure 1 below. The first five steps covered sample selection of information sources, identification and extraction of core text/data, development of analytical framework and organization of information. The steps 6 and 7 covered qualitative analytical process including content analysis of the text statements, and defining an overview of the discourse on emerging issues. The steps 8 and 9 encompassed the interpretation of content analysis and discussion on the issues in the light of International /UN Human Rights Conventions as well as developing guiding principles for the integration of human rights in a post disaster scenario. Finally, the documentation of the research process and its results was done at step 10 . 

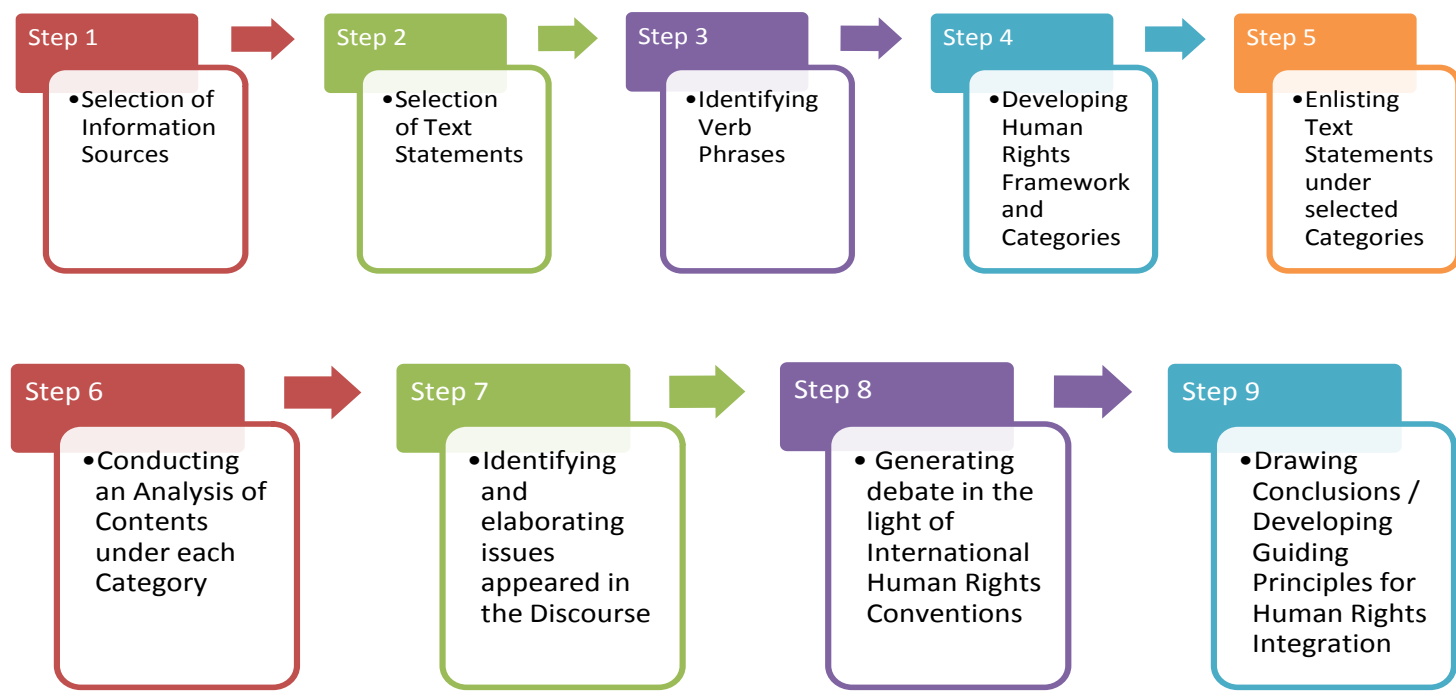

Step 10

- Preparing a Research Paper based on the above process

Figure 1. Methodology Process-Qualitative

\subsection{The Corpus}

The research corpus consisted primarily of a selection of thirty-two articles published in the magazine 'The Economist', two articles published in 'The Time Magazine' and seventeen Time Magazine newsfeed items published on website during 2011-2016, under titles of politics, economics/finance, science, technology, development and environment as well as special coverage of the disaster and technical reports on the disaster in Japan (annex 2). The Corpus was complemented with a random selection of a number of topical articles from many prestigious newspapers such as The Guardian, other international publications, journals and online sources. The main criteria for selection were the prestige of the magazine, its comprehensive coverage of topics and the language i.e. English. In addition, the cover page appeared on March 19, 2011 issue of 'The Economist' and headlines and sub headlines of selected articles in subsequent issues during the period of five years were included in the corpus.

\subsection{Analytical Techniques and Process}

Using guidance from the techniques of content analysis and critical discourse analysis as conceptualized by David Machin and Andrea Mayr [18], and Teun A. Van Dijk [19] and disseminated broadly, an analytical framework based on human rights' approach was developed encompassing the following four categories:
i. Natural/Fundamental Rights and Liberties
ii. Political and Socio-Economic Perspective
iii. Development, Technological and Environmental Perspective

\section{iv. Governance and Legal Perspective}

In the process each article and newsfeed item was screened to extract statements containing 'metapropositional' and 'discourse signalling' verbs and phrases that indicated actions, intended actions, action plans, policy debates and/or policy decisions, directives, strategies, financial plans, national and international agreements, announcements, promises and the state of affairs in one of the selected above-mentioned themes/categories [20].

The statements were further specified as positive, neutral and negative to identify gaps between the intended and actual actions and to gauge the extent and direction of change. Out of 100 statements, thirty eight were interpreted as positive, twenty two as neutral and forty as negative.

Finally, extracted information was placed under the human rights microscope and analyzed in the light of relevant international human rights conventions and legislation to understand social inequalities and power relationship among stakeholders. The available literature on Fukushima disaster was extensively used for raising consciousness on critical human rights issues that emerged from the analysis of post-disaster policy decisions.

Additionally, a selected cover page of the magazine and headlines/sub-headlines of various articles were interpreted in the context of current and historical use of English language. Most of the headlines/sub-headlines were formulated in abstraction and contained in-depth messages and lessons from the past. An overview of interpretations is presented in Annex 3. 


\subsection{Reporting of Research Findings}

The main challenge of this study was to identify from a wide range of information on diverse themes decisions made in the aftermath of the disaster that had an impact (positive or negative) on the lives of affected people within the broad human rights prospects.

The content analysis indicated that out of 70 verb phrases at least six were repeated more than once in the selected texts consisting of 100 statements. These were: announcing, building/rebuilding, changing, promising, reviving and starting/restarting. Besides, some phrases appeared during the year 2016 only such as attempting, continuing, redoubling efforts, resolving, resulting and revising in various contexts. Many of these denoted intent for change in situation. The phenomenon of 'Re' phrases was taken as an effort to do a better job than before.

It was also noted that in 2011 there were more positive statements than negative statements; the situation was reversed in 2012 and we found more negative statements than positive statements, particularly in categories 1,2 and
3. The status continued to fluctuate till 2016 as depicted below. There was no indication of a sustained incremental positive change.

There is no doubt that the authorities in Japan and the national and international actors had been consciously making efforts to restore the situation and normalize conditions for the evacuees to return home, and for the cleaning workers at the plant site to complete their job on schedule without compromising on the premise of public safety and occupational safety and health of workers. Nevertheless, there were huge challenges in delivering the desired results as could be seen from the forthcoming discussion.

The research findings on key decisions made by the Japanese authorities, as reported in the selected media articles and newsfeed, were incorporated in the following discussion including related issues and challenges faced both by the authorities and by the affected population in this process over a period of five years.

Table 1. Number of Extracts per Category per Year and Totals

\begin{tabular}{|c|c|c|c|c|c|c|c|c|c|c|c|c|}
\hline Year/ Number & & & & & & & & & & $\mathrm{Neq}$ & tive & \\
\hline & Cat. 1 & Cat. 2 & Cat. 3 & Cat. 4 & Cat. 1 & Cat. 2 & Cat. 3 & Cat. 4 & Cat. 1 & Cat. 2 & Cat. 3 & Cat. 4 \\
\hline 2011 & 7 & 7 & 0 & 0 & 2 & 2 & 0 & 2 & 1 & 5 & 2 & 0 \\
\hline 2012 & 1 & 2 & 3 & 1 & 0 & 4 & 2 & 0 & 7 & 5 & 3 & 1 \\
\hline 2013 & 1 & 3 & 0 & 0 & 1 & 1 & 0 & 0 & 0 & 0 & 0 & 0 \\
\hline 2014 & 0 & 4 & 2 & 0 & 0 & 0 & 0 & 0 & 0 & 0 & 0 & 0 \\
\hline 2015 & 0 & 1 & 0 & 0 & 1 & 1 & 0 & 0 & 3 & 0 & 0 & 0 \\
\hline 2016 & 0 & 1 & 4 & 1 & 2 & 4 & 0 & 0 & 5 & 6 & 2 & 0 \\
\hline \multirow{2}{*}{ Totals } & 9 & 18 & 9 & 2 & 6 & 12 & 2 & 2 & 16 & 16 & 7 & 1 \\
\hline & \multicolumn{4}{|c|}{38} & \multicolumn{4}{|c|}{22} & \multicolumn{4}{|c|}{40} \\
\hline
\end{tabular}

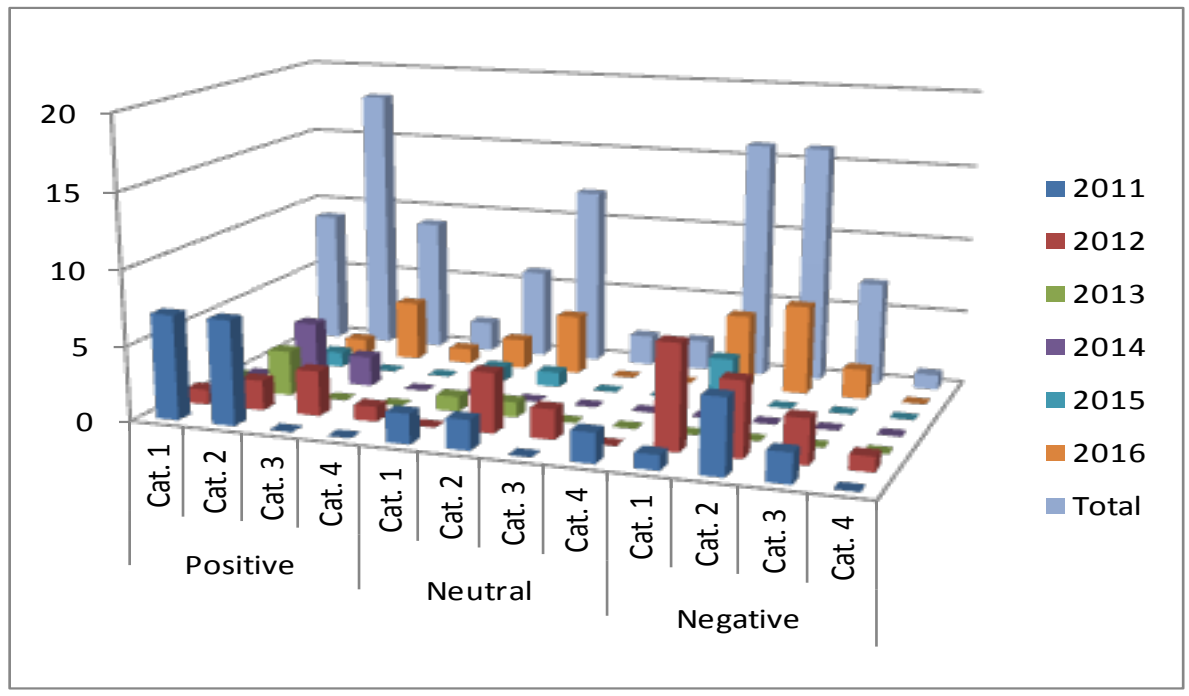

Figure 2. Representation of Categories 


\section{Discussion on Policy Decisions, Issues and Challenges}

\subsection{Natural/Fundamental Human Rights and Liberties}

The natural/fundamental human rights and liberties are drawn in the 'Bill of Rights' [21]. It includes individual's right to life, liberty, property, security and happiness.

Due to unprecedented devastation and damage to residential, civic and industrial physical infrastructure, the organizers and first responders in Fukushima encountered tremendous challenges in evacuation, particularly in transferring patients from hospitals and nursing homes within the $20 \mathrm{~km}$ circle [22]. Although the radiation leak was not as massive as the one occurred at Chernobyl, yet a large number of people was exposed to it, particularly workers; some of them seriously exposed to radiation were at a greater risk to develop cancer in the long-term [23]. Fukushima Medical University team was one of the responders to pick up workers who sustained injuries and contamination. In order to reduce the effects of radiation, they were required to wear personal protective equipment (PPE), monitored dose rate and minimized the time of stay on the site [24].

The International Atomic Energy Agency (IAEA) Director General's Report on Fukushima accident confirmed that ' $(\mathrm{t})$ he arrangements prior to the accident included criteria for sheltering, evacuation and iodine thyroid blocking in terms of projected dose, but not in terms of measurable quantities. There were no criteria for relocation' [25]. In the wake of disaster, the first priority was to save lives and to protect people from radiation exposure that was met with the incredible cooperation of the people during the evacuation process.

There were also concerns about the safety of 6000 workers engaged in the operation, some 2000 working close to the reactors [26]. The homes and means of livelihood including agricultural land, and agricultural and business enterprises were seriously impacted by the disaster.

Even after a lapse of 5 years 'around 100,000 evacuees were still homeless' [27] and due to widespread contamination of land and natural resources, returning home was not an easy decision to make for evacuees.

There were disparities in the sense of providing equal opportunities to all affected people in all affected areas. While the authorities were concentrating their efforts to rescue Fukushima Daiichi Power Plant, other coastal areas in the north east of Japan such as Kesennuma, Ofunato and Rikuzentakata were struggling on their own. In those areas, people were trying to rebuild their lives on self-help basis. As one journalist put it after a visit to Kesennuma, a fishing community badly hit by tsunami, that '(a) spirit of revival is in the air'. There was frequent display of such spirit everywhere in the town as 'people defiantly attempting to rebuild shattered lives' [28] despite a grave shortage of food and fuel in many coastal areas as most of the commodities were directed to Fukushima. The permission to transport fuel to north-eastern town took a long time due to bureaucratic procedures as the government did not declare the state of emergency early on to do away with petty regulations [29].

When the process for evacuees' return started, the compensation issue became the bone of contempt between the authorities and the victims because TEPCO indicated to end compensation payment for those who chose not to return home within the stipulated time. Many young parents with children were not inclined to return to areas which in their opinion still posed radiation risk to people, particularly to children. They felt that they were being compelled to go home, even though radiation exposure levels were still too high. The social and psychological effects of the disaster were not sufficiently covered in post Fukushima response.

Lessons from earlier disasters were not taken into account. For example, some ten years after Chernobyl, the Commission of the European Communities (CEC) and the Commonwealth of Independent States (CIS) collaborated to conduct a study "aimed at developing a better understanding of social and psychological factors in accident response for optimization of post disaster radiation protection [30]. The results were astounding. The conclusion showed that "the illness caused by increased stress within the affected populations would far outweigh the anticipated radiation health effects" [31].

\subsection{Political and Socio-economic Perspective}

There were many national concerns in which public participation was critical; however the authorities did not seem to pay sufficient attention. There was a fear of public show down at some point if the government persisted in its attitude to ignoring people's voices. Particularly, when the government announced plans to revitalize economy including restarting a few commercial reactors, it did not go well with the public. Public sentiments were displayed in antinuclear protests in Tokyo. One particular anti-nuclear protest that took place in Tokyo in July 2012 was reported to have mobilized around 170,000 people according to the unofficial reports and 75,000 people according to the official reports. It occurred as a reaction to government's indication to restart one or two nuclear power plants for economic reasons to spur growth and save money on import of fuel [32].

There was local opposition as three Municipalities in Japan had already shown determination not to reopen the plants in and/or close to their vicinity. The inclusion of public voices in the policy decision would have an impact on the government funding channelled to building commercial nuclear reactors [33]. Some 'critics do not believe that new technologies can sufficiently reduce the risk of nuclear energy to justify their imposition of a 
community' [34]. The antinuclear activists were asking for referendum to take into account the voices of Japanese people. They also emphasized the need for the authorities to develop renewable energy [35] for curtailing dependence on nuclear energy and safeguarding against future accidents.

The second issue was the intention of the government to join the Trans Pacific Partnership (TPP). The experts were of the opinion that the move towards joining TPP may cost the party votes from rural population who do not favour farm-trade liberalization [36].

The third issue at the political/economic scene was the announcement to raise the consumption tax and workers' wages to which both the public and the employers had reluctantly agreed

The government, however, had limited options. Due to the reduced capacity to generate electricity, Japan was faced with a $20 \%-30 \%$ shortfall resulting in power cuts [37]. The shortage of electricity and fuel together caused shut down of various industries that were providing a range of parts to manufacturers around the world, consequently halting their production. The worst hit was the auto and electronics industries. General Motors had to suspend production at a factory in Louisiana. Others trade partners including Thailand, Singapore and Taiwan in the region turned to Malaysia to meet their requirements [38]. Japan's industrial sector has insatiable demand for energy. With the shutdown of all fifty four nuclear power plants in the wake of Fukushima disaster, its fuel (oil and gas) import bill rose dramatically to ' $\$ 100$ million a day leaving the country with 'its first trade deficit in three decades' [39]. Although anti-nuclear feeling still existed among the public, the government focuses on improving the economic situation of the country. It was encouraging to learn that at one point, the government even expressed its intentions to include promotion of renewable energy in its new growth strategy and reform both health and education sectors [40].

Our research also revealed that 'Japan is the only country on the planet that has an earthquake early warning system (EWS) with capability for successful tsunami alert scheme equipped with 300 sensors scattered in territorial waters to predict an earthquake within minutes' [41]. The Japanese seismologists were able to detect seismic activities and had warned the authorities of 'a $99 \%$ chance of an earthquake of magnitude 8.0 occurring off the Miyagi coast, and a $90 \%$ chance of one off Ibaraki prefecture, within next 30 years' [42]. Geologically, Japan is prone to tsunami and earthquakes for centuries, yet the presence of a nuclear power plant on the site did not raise alarm for the authorities to prepare the public for an eventual contingency.

The issue of public information emerged as one of the policy shortcomings in the discourse. It was learned that the public was not adequately informed on the risk of living in the shadow of a nuclear power plant. There was no systematic public awareness programme in place that could have engaged various means of communication to reach out the public with a sustained flow of information, particularly through journalists who could use their journalistic acumen to take the information to targeted audience [43]. However, the individual and community discipline being one of the strongest national characters salvaged the situation.

Even after the disaster, the government was 'unable to pull together a crisis team involving experts from business and elsewhere that might give a sense of leadership on every front of the disaster' [44].

\subsection{Development, Technological and Environmental Perspective}

The impact of nuclear technology on development and environment is sector specific. The technological and infrastructure development as a result of investment in a new nuclear power plant up to the tune of $\$ 7.5$ billion to generate 1,000 megawatts of electricity [45] is politically a huge plus, but at what cost. It tilts the economic and social benefits in favour of urban population and deprives the rural communities of opportunities to develop and use local, environmentally friendly and socially beneficial alternate energy options. Private companies vehemently seek government support to build nuclear power plants for reasons to appease local opposition and to lessen financial burden on private investors [46].

We have accepted the fact that the radiation risk exists around us and something has to be done to protect the population at large. The world is currently dependent on more than 400 nuclear power reactors to meet around 20\% of its energy needs. The world has already seen a number of nuclear accidents including three serious accidents in the recent history. The radioactivity caused by the explosion and following leaks at Fukushima Daiichi Power Plant had been the main source of worry. The safety concerns have been raised time and again by experts who warned that "Don't imagine that it's safe simply because it has been historically safe" [47].

The nuclear industry has to address inter alia "issues of fuel security and concerns about the long-term management of radioactive waste" [48]. Particularly the issue of nuclear waste management is still unresolved globally, and dumping of waste in the poor neighborhood or keeping it floating at sea causes public concern all over the world. The intergenerational justice [49] is at stake as the present generation are benefiting hugely from the nuclear energy resources and leaving the task of waste management to the future generations.

In post Fukushima disaster scenario, sufficient information was not available to assess the gravity of the issue of nuclear waste management instantaneously. However, TEPCO's started to prepare and implement a road map for decommissioning the site over the next 30-40 years and to divert groundwater from the site as well as 
make arrangements to store a huge amount to avoid its infiltration. It is an encouraging development for the people and their living environment as well as for the future generation.

\subsection{Governance and Legal Perspective}

The nuclear power management's performance and attitude was reported to be stagnant, inefficient and complacent over a period of time which was revealed when the disaster occurred. The impact on society was much larger. The scientific community also suffered a loss of trust due to the accident according to the results of a survey conducted by the National Institute of Science and Technology Policy in Japan in November 2011 [50]. The nuclear power industry was described as 'fiercely tribal' and the 'regulators are too close to the utilities' which was one of the reasons for public scepticism [51]. The TEPCO was said to have had 'extraordinary industry influence on government regulators' [52].

Furthermore, people in Japan are culturally inclined to respect authority and avoid challenging their supervisor [53]. Thus, the more patience the public demonstrates, the more complacent the authorities become. The Fukushima accident afforded an opportunity to test and redefine this complex power relationship. Having reviewed the situation in the historical context, The Economist report concluded that '(f)or the best nuclear safety you need not just good planning and good engineering you need the sort of society that can produce accountability and transparency, one that can build institutions that receive and deserve trust' [54].

Regarding compliance with nuclear safety regulation, it was obvious that not only the plant managers were complacent but the regulators, too, did not do their duty with due diligence as reported by the IAEA [55]. The confidence of the managers in the nuclear power plant safety was shattered. 'At the time of the accident, the national legislation and guidance in Japan addressed measures to be taken for the protection of emergency workers, but only in general terms and not in sufficient detail' [56]. It let to public scepticism about the regulatory structure of nuclear industry.

The loss of trust was not confined to Japan. The public perception of nuclear risk, acceptance of nuclear power and the confidence in safety system dramatically and significantly decreased after the disaster; as a result many countries started to review their nuclear energy policies and programmes.

There were anti-nuclear protests in Europe. Germany's top power company E.ON had faced public disapproval instantly. The E.ON managers "were considered Germany's most influential business leaders" before the Fukushima disaster. It was no longer the case. Germany decided to shut down all of the 17 nuclear power plants by 2021 causing E.ON a loss of 22 billion Euros in profits [57].
A before and after survey conducted in a city near a nuclear power plant in China revealed that the risk perception of the Chinese public, especially the factor perceived risk increased from 'limited risk' to 'great risk' on a five- point Likert scale [58]. Many countries in Asia and Pacific including India and Pakistan reviewed the safety systems and designs of all the nuclear power reactors in response to Fukushima disaster whereas Australia announced that there was no role of nuclear energy in its future [59].

The ray of hope emerged when during the year 2012; the Japanese government discussed the prospects of appointing an independent regulator to assure safe restarting and running of $\mathrm{Ol}$ nuclear power plant in Fukui Prefecture. After the change of political leadership in December 2012, the new government strongly pursued the plan to restart a few commercial reactors, and simultaneously revamped the Nuclear Regulatory Authority set up, giving it more independence to issue clearance for the restart after reassuring compliance to safety regulations [60].

\section{Conclusions}

The natural/fundamental human rights and socio-economic issues during emergency evacuation and subsequent response phase posed enormous challenges that needed a delicate balance between imposing government decisions and yielding to the desires of people. For example the home return options for evacuees needed a passionate consideration for diversity, to give youth a chance to relocate at a place of their choice with young children to enhance opportunities for safe and gainful socio-economic living conditions. Other issues included public dissent on the continued use of nuclear energy, lack of trust in the bureaucratic government systems and inadequacy of TEPCO management. Due to the lack of communication and inland security reasons, people were at the short end of receiving or sharing information, especially with media representatives.

In short it is provisionally concluded that the situation has not changed to meet the expectations of general public. At least the picture emerged from the above qualitative analysis did not show a visible impact of policy decisions on the overall state of affairs. Quite a many issues still persisted, particularly in the following major areas of concern.

- Rehabilitation process of evacuees was not completed till the time of reporting as of March 2016. Around 100,000 evacuees were still living in temporary accommodation; some were not keen to return due to fear of radiation risk to their children despite being faced with the loss of compensation.

- The health impact of radiation on the affected population in the short, medium and long term was not researched in order to develop a radiation protection 
health programme to monitor the health status of the people for a prescribed period of time and to establish a specialized branch of cancer health services to ensure that any future cancer incidence among the affected population would be addressed.

- Economy showed slow recovery despite the government's efforts to use many fiscal, monetary and trade measures. It was a source of worry for the government as it affected the approval rate of the present political leadership. Two main concerns were (i) the shrinking rate of growth and (ii) postponement of promised consumption tax hike twice during the period. It finally came through.

- The government could not keep its promise to do away with nuclear energy and was forced to restart a few commercial nuclear power plants for economic reasons despite public opposition. No clear agenda about promoting renewable energy was on the horizon.

- The radiation risk in and around the area of Daiichi Power Plant was still looming large, part of which was cordoned off from public access. It will take time to remove all the debris/waste from the location and shift to secure places for burial. The nuclear waste management strategy is yet to be publicly debated.

- $\quad$ So far (March 2016), there seemed no material efforts or public campaigns by the authorities to engage people in policy debates to rebuild public trust and sort out national priorities, particularly related to the continued use of nuclear power.

In our view, it is too early to draw concrete lessons from the post disaster policy decisions as the situation is still unfolding; however some future prospects can be discussed to integrate human rights in anticipation that the respective authorities may take notice.

\section{Human Rights Integration in Post Disaster Scenario}

The human rights premise is based on a multi-dimensional structure of universal value system adopted by the international community at UN and other international and regional forums. Details are provided in section 1.2. The foregoing discussion and conclusions helped us to identify priority areas where there are possibilities to integrate human rights in the governance system to benefit the affected population, as follows.

\subsection{Rehabilitation of Evacuees}

Three human rights prospects are being discussed with regard to on-going rehabilitation process: (i) freedom of movement, (ii) parents' right to decide about the future of their children and (iii) child rights.

The Fukushima disaster has created an acute situation in which actual risk may not be as high as the perceived risk; therefore, the authorities have to take into account the psychological impact of the disaster on evacuees while dealing with the rehabilitation process. It is also an integral part of the right to health discussed later in this section. Besides damaging physical, economic and social infrastructure, the disaster also provided an opportunity to have a fresh look at the social needs of specific groups of people within the society and direct national energies to making positive changes at both individual and community level.

The Universal Declaration of Human Rights (UDHR), the International Covenant on Civil and Political Rights (ICCPR), the American Convention on Human Rights, the European Charter of Fundamental Rights as well as African and Arab Human Rights Charters uphold the right of citizens to move freely his/her residence within the country and abroad and to return. As elaborated in The UDHR Article 13.1; 'Everyone has the right to freedom of movement and residence within the borders of each State' [61].

Bringing the above point home in the light of psychological impact of the disaster, we argue that evacuees' repatriation under financial pressure might create further stress to individuals and families who had already lost all their assets, home and livelihood, and were undergoing a drastic change in life. Especially, the young parents of children had expressed concern about returning home due to persisting fear of radiation risk. They were faced with the dilemma of either putting the health and well-being of their families at risk or giving up compensation benefit.

The decision about the allocation or suspension of compensation may be justified on the basis of equality, however, it does not meet the 'substantive understanding of justice' according to which the 'outcome is the main concern of justice' [62]. Hence, the outcome in this case is the protection of children and ensuring that the best interest of the child is being served. If parents were not satisfied with the prospects of resettling in the radiation affected areas where all the education, health, recreation and business activities were not fully functional, it might deprive children from enjoying the full benefits of educational, social and cultural life as provided under the Convention on the Rights of the Child (CRC).

The ICESCR Article 13.3 protects parental rights of child education which could be a source of guidance in this case. It declares that, 'The States Parties to the present Covenant undertake to have respect for the liberty of parents and, when applicable, legal guardians to choose for their children schools, other than those established by the public authorities, which conform to such minimum educational standards as may be laid down or approved by the State and to ensure the religious and moral education of their children in conformity with their own convictions, [63]. 
Therefore, parents' decision to change their residence for protecting their children from hazard and to choose educational institutions for them to be respected without depriving them of benefits awarded as evacuees.

\subsection{Protection from Radiation Side-effects in the Short, Medium and Long Term}

Under radiation protection, prospects of (i) citizens' right to health and (ii) workers' right to occupational safety and health are being considered.

Right to Health: Protection from radiation risk is well covered under the 'Right to Health' by international and regional human rights conventions and globally supported by the UN specialized agency the World Health Organization (WHO).

'Right to Health' and 'Right to Adequate Standard of Living' go hand in hand. According to UDHR Article 25: 'Everyone has the right to a standard of living adequate for the health and well-being of himself and of his family, including food, clothing, housing and medical care and necessary social services, and the right to security in the event of unemployment, sickness, disability, widowhood, old age or other lack of livelihood in circumstances beyond his control'.

The ICESCR Article 12.2 (c) and (d) provides that, '... steps to be taken by the States Parties to the present Covenant to achieve the full realization of this right shall include those necessary for:

(c) The prevention, treatment and control of epidemic, endemic, occupational and other diseases; (d) The creation of conditions which would assure to all medical service and medical attention in the event of sickness' [64].

From the above statements, we argue that not only the health care, but the living conditions and environment are also included in the broader concept of the right to health.

Nuclear plant explosions release 'ionizing radiations having intense immediate and long terms adverse effects on human beings and environment' [65]. In the post disaster situation, the concerned authorities have the responsibility to ensure people's 'Right to Health' that includes all physical, mental and psychological aspects, adequate standards of living and congenial environment. This supports the case of parental fears of radiation risk to health and the desire to protect their children. Other vulnerable groups include the elderly, the infirm and the women, in particular the expectant mothers whose own health and the health and well-being of their future babies is to be protected from short term and long term radiation after effects. The guidance should also be taken from the UN Convention on the Elimination of All Forms of Discrimination against Women (CEDAW).

As reported, the public health system was damaged in the affected areas closing down a number of hospitals due to evacuation within the vicinity of Fukushima Daiichi Power Plant. As a result there was tremendous pressure on the available medical facilities in the surrounding areas and other parts of the country to provide health services both to evacuees and to workers. In such an emergency, it was not possible to plan and conduct a thorough research on the health impact of radiation on the affected population in the short, medium and long term. Five years down the line, time is ripe to develop a radiation protection health programme to monitor the health status of affected population over a period of time and to establish a specialized branch of cancer health services to ensure that any future cancer incidence among the affected population would indisputably be addressed in the context of citizens' Right to Health.

This kind of service will help to develop specific knowledge of the side effects and/or after effects of nuclear fallout and will serve not only Japan but the global humanity.

Right to Occupational Safety and Health: The World Health Organization (WHO), the International Labour Organization (ILO) and the International Atomic Energy Agency (IAEA) are the major proponents of the 'Right to Occupational Safety and Health (OSH)'. Please refer to section 1.2 of the paper.

Occupational health is a multidisciplinary field of healthcare concerned with enabling an individual to undertake occupation, in the way that causes least harm to health. It is concerned with preventing harm from any incidental hazards, arising in the workplace [66].

The ICESCR Article 7, (ii) (b) further declares that: 'The States Parties to the present Covenant recognize the right of everyone to the enjoyment of just and favourable conditions of work which ensure, in particular: (b) Safe and healthy working conditions;...[67]'. Likewise Article 30 of Euroatom Treaty lays down 'basic standards within the community for the protection of the health of workers and the general public against the danger arising from ionizing radiation' [68]

The situation of Fukushima disaster clean-up workers was more precarious than the members of general public as they (workers) had been directly exposed to radiation as part of their cleaning duties. During our research we learned that, 'it is hard to definitively prove a causal relationship between radiation and disease, whether physical or mental' [69]. If that is the case, then the scientific community has not come up to the expectations of humanity. Three colossal nuclear disasters were enough to raise the level of responsibility to conduct an in-depth research and collect evidence to clearly define the causal relationship either way.

We argue that there are many options to address this issue. One possibility is to provide universal health insurance coverage for potential cancer to all clean-up workers till the correlation between the radiation exposure and the disease of cancer is scientifically established as a rule. It will save thousands of workers from unnecessary physical, emotional, mental and financial distress. The 
OSH is a fundamental human right and is upheld in numerous international conventions as quoted above. The ILO, being a tripartite organization, is an appropriate forum to look into this matter.

\subsection{Economic Recovery, Rebuilding and Continued Use of Nuclear Energy}

The above issues are inter-related and are being looked at from the perspective of (i) sustainable development and (ii) environmental protection as follows:

Economic recovery and rebuilding in post disaster Japan is heavily dependent on nuclear technology as we have learned from the foregoing discussion. Globally, technology has a tremendous impact on development, both positive and negative. It creates opportunities for people to produce goods and services on one hand and disparities in resource distribution among various groups of populations on the other. Concentration of government bureaucracies and corporate businesses in capital cities deprives people in other towns of resources to attain the same level of development and prosperity and enjoy the same standards of life. It is where the governments are required to take balanced decisions.

The subject of sustainable development and environmental protection has been covered in many international and regional conventions including the ICESCR that ensures equal right of men and women to the enjoyment of all economic, social and cultural rights including adequate standards of living. The European Union Charter of Fundamental Rights, Article 37 prescribes: 'A high level of environmental protection and the improvement of the quality of the environment must be integrated into the policies of the Union and ensured in accordance with the principles of sustainable development' [70].

In the case of Japan, the post-disaster rebuilding provides an opportunity to invest in local public infrastructures and business, particularly in coastal areas where fishing communities had suffered huge loss of assets to support sustainable livelihood that 'requires attention to inter and intragenerational equity, adequate standards of living for all individuals, and concern for the environment' [71].

Japan is moving towards creating a new vision for the future that 'relate to the type of country it want to be. One consideration is to look at the unequal distribution of resources and opportunities due to the concentration of population, government and industry in Tokyo' [72], and initiate progressive devolution of authority, including financial authority to encourage local governments and municipalities to take control of their own development agenda, with regard to inter alia energy policy should they wish to invest in renewable energy technology. This will support the national aspirations to ensure sustainable energy development, and address the safety and security issues in a way to minimize the risk to people, their living conditions and the environment.

The world is faced with a real dilemma as the "sustainable development promotes opportunities in a secure manner" [73], which may be threatened by nuclear accidents and risk of radiation leaks. Securing adequate quality of life including basic human right to health, education, livelihood, right to participation in civil and political activities and protection of environment across generations is critical under the circumstances when there were still issues with the safety and security aspect of the nuclear energy compared to other sustainable energy sources [74].

\subsection{Public Engagement and Rebuilding Public Trust}

The engagement of people in policy decision making and rebuilding trust have vast prospects for the integration of human rights including (i) public participation, (ii) right to information and (iii) transparency in communication.

Regarding public participation, we refer to UDHR Article 21 that stipulates that; 'Everyone has the right to take part in the government of his country, directly or through freely chosen representatives'. And 'Everyone has the right to equal access to public service in his country' [75].

Absence of public participation in important policy decision making and priority setting cannot be more damaging than during crisis of the size of Fukushima. Failing to notice public voices may cost the government public votes and removal from the political leadership. It may also cause conflict between the government and normally peaceful populace. In such fragile situations, 'customer (stakeholders) trust should be considered an essential part of risk identification' [76].

The impact of the natural catastrophe gave a serious blow to Japan's economy. In fact together with other natural catastrophes occurred around the world, the year 2011 was termed the 'costliest on record for natural disasters' [77].

Preoccupied with the challenge to revive economy and trade which was hampered by the disaster, the present government took upon itself the task of priority setting without sufficient deliberations at public forums to ensure public participation on issues such as restarting the nuclear reactors or joining TPP. The members of the public in Japan were concerned about their safety, and so was the global community as exclaimed by one expert, "(t)he recent accident at Fukushima nuclear plant has made us more worried about the safety of nuclear power and opened the chapter of many debates and controversies about the usage and utilization of nuclear energy" [78].

Furthermore, it was not possible to satisfy the 'growing public expectations of transparency and participation' [79] without sharing necessary, accurate and timely information on nuclear risk. The political reality is that 'in all 
democratic systems, public opinion matters to the extent that politicians care about being re-elected' [80]. This mindset has to change in order to strengthen democracy in Japan. The suggestion by protesters to hold a referendum to include public opinion in policy making was worth the consideration by the authorities.

Regarding right to information, guidance is available in UDHR Article 19 in which it is declared that: 'Everyone has the right to freedom of opinion and expression; this right includes freedom to hold opinions without interference and to seek, receive and impart information and ideas through any media and regardless of frontiers' [81].

Likewise, the Right to Information is being upheld in almost all the international and regional human rights charters. Dissemination of information and creating awareness about potential radiation risk is an essential part of public information system that helps to build public trust in fragile circumstances such as faced during Fukushima disaster. Although people in Japan showed a lot of patience and discipline during evacuation, knowing the extent of potential risk earlier could have prepared them better to react in emergencies.

Lack of information coupled with the delay in fixing responsibility for the Fukushima Daiichi Power Plant fallout became a cause of contention and distress to the affected communities. The results of recent opinion polls revealed that voters had lost faith in both (political parties) [82].

With regard to nuclear power governance system and the public trust, the fact is that both governance and trust are elements of the national culture and as such their relationship is deep rooted in the society. Stakeholders' trust is an important part of risk management [83]. There is empirical evidence that the governance and (culture of) public trust are correlated and that relationship plays an important part in managing risk. 'Trust determines how and whether risk-control measures will be accepted and will be effective', [84] writes Kazuya Nakayachi quoting many scholarly sources in his article while discussing the case of the erosion of trust in nuclear governance system after Fukushima disaster.

The lesson drawn from the above statements is that the transparency in communication is all the more important during emergencies for winning public support.

\section{Future Outlook}

\subsection{What Kind of Change Is Underway in Japan?}

The Fukushima accident is an opportunity for the government to take people into confidence for future decision making on continued use and expansion of nuclear energy. The "nuclear power casts light on the way governments practice governance and the extent to which they can engage in metagovernance" [85]. From conceptual point of view, the 'metagovernance' has a strong element of government's relationship with society and the social actors in the nuclear industry [86]. This requires educating the global audience as well as national public on policy matters that need public support.

The change is imminent in the Japanese political, economic and social systems as well as in governance and legal set up. It could be technology driven as such opening avenues to innovation and development in renewable energy or culturally motivated to bridge the generation gap, show more sensitivity and respect to public opinion, particularly to youth; or change in thinking on humanitarian issues to protect the rights of internally displaced persons (evacuees) and externally displaced persons (refugees/asylum seekers) [87] and the occupational safety and health of industrial workers in general and nuclear power plant workers in particular.

Change is also foreseen in governance and legal outfit to dilute centralization and delegate more authority to local governments to draw up reconstruction plans, funded from the national budget [88]. Safety regulations and safety infrastructure of nuclear power plants is due for an in-depth revision and training of respective stakeholders including public education on radiation risk.

Some sporadic challenges in the way of change were also noted during the research, which give mixed vibes. For example, regarding labour market liberalization, the government seems to have 'no menu of reforms' [89] on the agenda.

Change in the constitution is not popular among the pacifists.

\subsection{Who Are the Proponents of Change?}

The right question to ask is 'who will be the proponents of change?' Why? Because the country is not yet out of the crisis and many a decisions are taken to support post-disaster rebuilding. The flexibility shown by the federal government to delegate authority to local governments for rebuilding coastal towns and communities has two main advantages: (i) the local governments will be accountable to people in case the progress or performance does not meet the demands and aspirations of the people, and (ii) the federal government would get the credit without engaging itself in the hard task of rebuilding.

It is fair enough as long as the communities receive the goods and services to rebuild their homes and livelihood, and get back to normal life. This could be one off action which may not sustain after the rebuilding project is completed and the funds earmarked for it are exhausted. What will happen then? Will there be a proposal to delegate responsibility to local governments to decide the future development direction of the municipalities e.g. adopting renewable energy technology. More importantly, will the voices of local representatives of the public will be 
included in the decisions regarding the use of nuclear power.

From among the public, civil society, workers, media and youth could be effective proponents of change, influencing the future direction of the country and the nation, should the basic human rights and liberties, in particular, the right of expression and freedom of speech are made the corner stone of the government policy, public trust is rebuilt and public participation and dissent opinion are ensured in the process of policy decision making.

\section{Final Remarks}

The main concern remained that the inherent risk in nuclear power has not been given the attention by the international community in the past it deserved, particularly the obligation of government authorities to uphold human rights affected by public policy and decision making in the aftermath of serious nuclear disasters.

It is unrealistic to hope that there will not be any more Chernobyl or Fukushima in the future. The global community has to wake up to the risk inherent in nuclear technology and raise both safety standards and human values. The political agenda of safe and secure application of nuclear energy and the public agenda of human rights to protect population, property and environment are mutually inclusive.

A stricter inspection regime is not enough. There has to be a social monitoring and evaluation mechanism in collaboration with non-profit and non-governmental stakeholders to ensure protection of human rights and fundamental freedoms in the nuclear power sector, during normal conditions and in crisis.

\section{Limitations of the Study}

The primary corpus of this study is limited to two main sources of information 'The Economic' and 'The Time Magazine' both articles and electronic newsfeed with their particular journalistic outlook on issues. In order to mitigate that selection bias on our part and to provide a broader, more diverse and comprehensive perspective, the corpus was complemented with material from many other journalistic and media sources, technical and scholarly reports including the highly credible 'The Fukushima Daiichi Accident Report by the Director General, International Atomic Energy Agency (IAEA) GC (59)/14, $2015^{\prime}$ to back up technical and scientific information. All sources are quoted in the reference section.

\section{Annex 1. References from International and Regional Human Rights Instruments}

\begin{tabular}{|c|c|c|c|c|c|c|c|c|c|}
\hline & Human Right & UDHR & ICCPR & ICESCR & CPHR\&FF- & EU-CFR & $\mathrm{ACHR}$ & ACHRPR & ACHR \\
\hline 1 & $\begin{array}{l}\text { Right to life, liberty, dignity and } \\
\text { security of person }\end{array}$ & Art.3 & $\begin{array}{l}\text { Art.6, } \\
\text { Art.9 }\end{array}$ & & $\begin{array}{l}\text { Art.2, } \\
\text { Art.5 }\end{array}$ & Art.2 & $\begin{array}{l}\text { Art.4, } \\
\text { Art.5, } \\
\text { Art.7 }\end{array}$ & $\begin{array}{l}\text { Art.5, } \\
\text { Art.5, } \\
\text { Art.6 }\end{array}$ & $\begin{array}{l}\text { Art.5, } \\
\text { Art.11, } \\
\text { Art.14 }\end{array}$ \\
\hline 2 & Right to equality and justice & Art.7 & Art.14 & Art.3 & Art.14 & $\begin{array}{l}\text { Art.20, } \\
\text { Art.23 }\end{array}$ & Art.24 & Art.3 & \\
\hline 3 & Right to adequate standards of living & Art.25 & & Art.11 & & & & & $\begin{array}{l}\text { Art.38, } \\
\text { Art.39 }\end{array}$ \\
\hline 4 & $\begin{array}{l}\text { Right to participation/Right to } \\
\text { self-determination/equal excess } \\
\text { public service }\end{array}$ & Art.21 & $\begin{array}{l}\text { Art.1, } \\
\text { Art.25 }\end{array}$ & Art.1 & & $\begin{array}{l}\text { Art.36, } \\
\text { Art.39 }\end{array}$ & Art.23 & Art.13 & $\begin{array}{l}\text { Art.2, } \\
\text { Art.24 }\end{array}$ \\
\hline 5 & $\begin{array}{l}\text { Freedom to expression/ } \\
\text { Right to information }\end{array}$ & Art.19 & Art.19 & & Art.10 & $\begin{array}{l}\text { Art.11, } \\
\text { Art.27 }\end{array}$ & Art.13 & Art.9 & Art.24 \\
\hline 6 & $\begin{array}{l}\text { Right to enjoy physical and mental } \\
\text { health }\end{array}$ & Art.25 & & Art.12 & & Art.35 & & Art.16 & \\
\hline 7 & $\begin{array}{l}\text { Right to work/just and favourable } \\
\text { conditions of work }\end{array}$ & Art.22 & & $\begin{array}{l}\text { Art.6, } \\
\text { Art.7 }\end{array}$ & & Art.15 & & & \\
\hline 8 & $\begin{array}{l}\text { Right to occupational safety and } \\
\text { health }\end{array}$ & & & Art.7 & & Art.31 & & & \\
\hline 9 & Freedom of movement & Art.13 & Art.12 & & & Art.45 & Art.22 & Art.12 & Art.26 \\
\hline 10 & $\begin{array}{l}\text { Right to Social Security, Social } \\
\text { Insurance }\end{array}$ & & & Art.9 & & & & & Art.36 \\
\hline 11 & Right to Human Rights education & & & & & & & & \\
\hline 12 & $\begin{array}{l}\text { Right to development/ Scientific } \\
\text { development }\end{array}$ & & & Art.15 & & & & Art.22 & \\
\hline 13 & $\begin{array}{l}\text { Sustainable development/ } \\
\text { Environmental protection }\end{array}$ & & & & & Art.37 & & & \\
\hline 14 & Right to good governance & & & & & Art.41 & & & \\
\hline
\end{tabular}


Full titles of International and Regional Human Rights Instruments:

- UDHR: Universal Declaration of Human Rights (1948)

- ICCPR: International Covenant on Civil and Political Rights (1966)

- ICESCR: International Covenant on Economic, Social and Cultural Political Rights (1966)

- CPHR\&FF: Convention for the Protection of Human Rights and Fundamental Freedoms, as amended by Protocols No. 11 and 14 (1950) and Protocols - Europe

- EU CFR: EU Charter of Fundamental Rights (2000)

- ACHR: American Convention on Human Rights (1969), and Additional Protocols

- ACH\&PR: African Charter on Human and Peoples' Rights (1981)

- ACHR: Arab Charter on Human Rights (2004)

- Vienna Declaration and Programme of Action (1998)

- WHO: World Health Organization's Cancer Policy and Programme

- ILO: International Labour Organization's Convention on Occupational Safety and Health

- IAEA: International Atomic Energy Agency's Basic Safety Standards

\section{Annex 2. The Corpus}

\section{The Economist Articles}

1. The Fall Out, The Economist, March 19th 2011

2. Briefing Japan's Catastrophe-Nature Strikes Back, The Economist, March 19th 2011

3. Briefing Japan's Catastrophe-Japan's Nuclear Industry - The risks exposed, The Economist, March 19th 2011

4. The world Economy, From tsunamis to Typhoons, the Economist, March 26th 2011

5. Disaster in Japan, Come Back in ten years' time, The Economist, March 26th 2011

6. Briefing Nuclear Power, When the steam clears, The Economist March 26th 2011

7. Natural disasters, The rising cost of catastrophes, The Economist, January 14th 2012

8. Special Report on Nuclear Energy, The Economist, March 10th 2012

9. The dream that failed, The Economist, March 14th, 2012

10. Japanese Politics, Hair Shirts, The Economist, March 24th 2012

11. Politics in Japan, The Unlikely Mr. Noda, The Economist, June 16th 2012

12. Japan's Fiscal Mess, A pound of flesh, The Economist, June 23rd 2012
13. Japan's Ichiro Ozawa, A shadow of a shogun, The Economist, June 30th 2012

14. Japan's anti-nuclear protests, The heat rises, The Economist, July 21st 2012

15. Disaster and Demography in Japan, Generational Warfare, The Economist, August 4th 2012

16. Japan's Energy Security, Foot on the gas, The Economist, September 22nd 2012

17. Nuclear Workers in Japan, Heroism and humility, The Economist, October 27th 2012

18. Corporate governance in Japan, Olympian depths, The Economist, November 3rd 2012

19. Japan's nuclear future, Rokkasho and a hard place, The Economist, November 10th 2012

20. Japan's election, Pole dancers, The Economist, November 24th 2012

21. Japanese Politics, Mutton dressed as lamb, The Economist, December 8th 2012

22. Japan and America, Spin and substance, The Economist, March 2nd 2013

23. Forestry in Japan, Killing two birds with one tree, The Economist, March 9th 2013

24. Japan and free trade, Better late than never, The Economist, March 23rd 2013

25. Nuclear Power in Japan, Start 'em up, The Economist, March 8th 2014

26. Japan's consumption tax, The big squeeze, The Economist March 29th 2014

27. Japan and the past, undigested history, The Economist, March 7th 2015

28. Japan's asylum laws, No entry, The Economist, March 14th 2015

29. China, Japan and South Korea, The buds of March, The Economist, March 28th 2015

30. Japanese Politics, Abe agonistes, The Economist, March 12th 2016

31. Japan's male only emperor system, Imperial Lather, The Economist, March 19th 2016

32. China, Nuclear Power, A glowing future, The Economist, September 24th 2016

\section{The Time Magazine Articles and Newsfeed}

1. Rebuilding Japan, The Time Magazine, July $04^{\text {th }}$ 2011.

2. Five Years after the meltdown, Is it safe to live near Fukushima? By Dennis Normile, Science, The Time Magazine, March $2^{\text {nd }} 2016$.

3. http://content.time.com/time/specials/packages $/ 0,2$ $8757,2058716,00 . \mathrm{html}$

4. http://content.time.com/time/world/article/0,8599, 2099119,00.html

5. http://content.time.com/time/world/article/0,8599, 2097511,00.html

6. http://content.time.com/time/world/article/0,8599, 2095296,00.html 
7. http://content.time.com/time/world/article/0,8599, 2090572,00.html

8. http://content.time.com/time/world/article/0,8599, 2086427,00.html

9. http://content.time.com/time/world/article/0,8599, 2083703,00.html

10. http://content.time.com/time/world/article/0,8599, 2081820,00.html

11. http://content.time.com/time/magazine/article/0,91 $71,2079476,00 . h t m l$

12. http://science.time.com/2011/06/14/tokyo-will-hel p-compensate-nuclear-victims/

13. http://science.time.com/2011/06/08/fukushima-ne w-report-suggests-fuel-burned-through-vessels/
14. http://content.time.com/time/nation/article/0,8599, 2076195,00.html

15. http://world.time.com/2011/05/23/tomato-diploma cy-will-fukushima-bring-china-and-japan-together /

16. http://content.time.com/time/magazine/article/0,91 $71,2059619,00 . h t m l$

17. http://content.time.com/time/magazine/article/0,91 $71,2059639,00 . \mathrm{html}$

18. http://science.time.com/2011/06/01/iaea-japan-und erestimated-risk-to-nuclear-facility/

19. http://science.time.com/2011/05/27/on-japans-coa st-tensions-with-activists-still-run-high-after-tsuna $\mathrm{mi} /$

\section{Annex 3. An Interpretation of Selected Cover Page and Headlines/Sub-headlines}

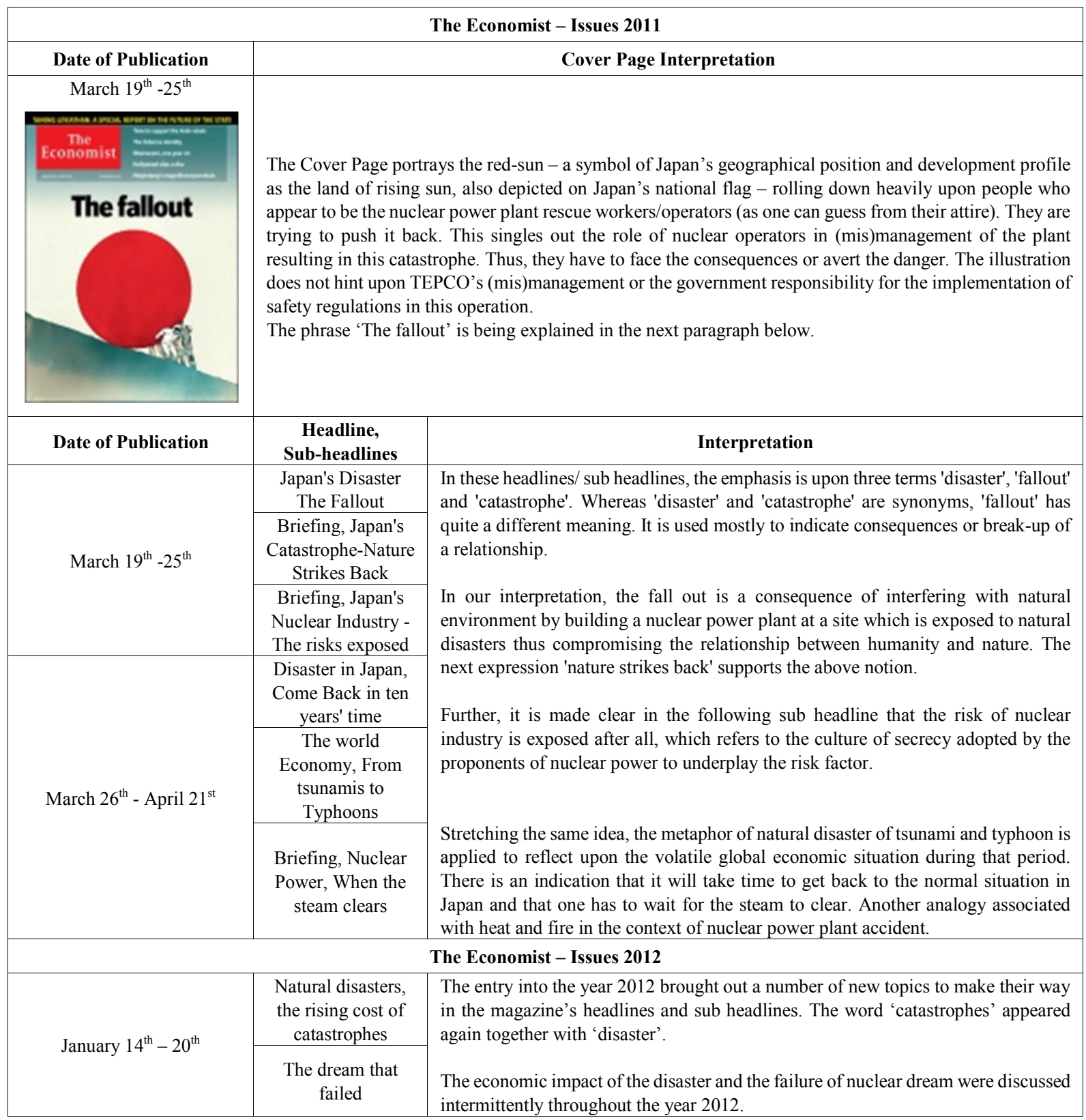




\begin{tabular}{|c|c|c|}
\hline \multicolumn{3}{|r|}{ The Economist - Issues 2013} \\
\hline $\operatorname{March} 2^{\text {nd }}-8^{\text {th }}$ & $\begin{array}{l}\text { Japan and America, } \\
\text { Spin and substance }\end{array}$ & $\begin{array}{l}\text { The relationship between Japan and the USA has been multi-faceted including } \\
\text { defense agreement and industrial cooperation particularly in auto manufacturing } \\
\text { which suffered due to Fukushima accident as auto spare parts could not be } \\
\text { manufactured for supply to US counterparts due to shortage of energy. The headline } \\
\text { does not communicate much what has been said in the article. The word 'Spin' } \\
\text { appears to indicate some twirling in relationship whereas from the article it is } \\
\text { gathered that it refers to the spin in Japanese economy and politics. The headline is } \\
\text { formulated in abstraction. }\end{array}$ \\
\hline March $9^{\text {th }}-15^{\text {th }}$ & $\begin{array}{c}\text { Forestry in Japan, } \\
\text { Killing two birds } \\
\text { with one tree }\end{array}$ & \multirow{3}{*}{$\begin{array}{l}\text { The second headline is focused on an internal decision about forestry in Japan that is } \\
\text { expected to result in gaining profit in two areas i.e. clearing a particular type of tree } \\
\text { that causes allergy and using the lumber in rebuilding houses in the disaster affected } \\
\text { areas. The English idiom 'Killing two birds with one stone' is modified by } \\
\text { substituting 'stone' analogy with 'tree'. The third headline points to Japan's belated } \\
\text { consideration to join free trade agreement called TPP following the meeting } \\
\text { between the US President and the Japanese Prime Minister covered under the first } \\
\text { headline. } \\
\text { "The Trans-Pacific Partnership (TPP), or the Trans Pacific Partnership Agreement } \\
\text { (TPPA), is a trade Agreement between Australia, Brunei, Canada, Chile, Japan, } \\
\text { Malaysia, Mexico, New Zealand, Peru, Singapore, the United States (until } 23 \\
\text { January 2017) and Vietnam. A final agreement was drafted on } 5 \text { October } 2015 \text {, } \\
\text { made public on } 5 \text { November } 2015 \text {, and signed on } 4 \text { February } 2016 \text { in Auckland, } \\
\text { New Zealand, concluding seven years of negotiations. It is the largest trade } \\
\text { agreement in history." } \\
\text { (https://en.wikipedia.org/wiki/Trans-Pacific_Partnership) }\end{array}$} \\
\hline & & \\
\hline $\operatorname{March} 23^{\text {rd }}-29^{\text {th }}$ & $\begin{array}{l}\text { Japan and free } \\
\text { trade, Better late } \\
\text { than never }\end{array}$ & \\
\hline \multicolumn{3}{|r|}{ The Economist - Issues 2014} \\
\hline $\operatorname{March} 8^{\text {th }}-14^{\text {th }}$ & $\begin{array}{l}\text { Nuclear Power in } \\
\text { Japan, Start 'em up }\end{array}$ & \multirow{2}{*}{$\begin{array}{l}\text { The focus continued to be on economic issues, two of which made headlines: } \\
\text { nuclear power and consumption tax. In the backdrop of rising cost of imports of fuel } \\
\text { and consequent budget deficit left no choice for the government, but to restart the } \\
\text { nuclear power plants. } \\
\text { The 'big squeeze' refers to the consumption tax expected to put an extra burden on } \\
\text { population in the aftermath of the disaster. The phrase is also frequently being used } \\
\text { in the context of corporate investment in the international markets including the } \\
\text { USA. }\end{array}$} \\
\hline March $29^{\text {th }}-$ April $4^{\text {th }}$ & $\begin{array}{c}\text { Japan's } \\
\text { consumption tax, } \\
\text { The big squeeze }\end{array}$ & \\
\hline \multicolumn{3}{|r|}{ The Economist - Issues 2015} \\
\hline $\operatorname{March} 7^{\text {th }}-13^{\text {th }}$ & $\begin{array}{l}\text { Japan and the past, } \\
\text { undigested history }\end{array}$ & $\begin{array}{l}\text { Japan's defeat in the WWII and subsequent decisions are a source of concern for } \\
\text { many politicians, in particular in the changing geo-political scenario and alliances. } \\
\text { The use of the phrase 'undigested' reflects a constant qualm over the past and } \\
\text { indicates future prospects of change. Some of which are focused on building own } \\
\text { defense system and nuclear capability to reduce reliance on allies. }\end{array}$ \\
\hline \multicolumn{3}{|r|}{ The Economist - Issues 2016} \\
\hline March $12^{\text {th }}-18^{\text {th }}$ & $\begin{array}{l}\text { Japanese Politics, } \\
\text { Abe agonists }\end{array}$ & \multirow{2}{*}{$\begin{array}{l}\text { The phrase 'Abeagonistes' is coined as an analogy for agonies or worries on the } \\
\text { pattern of other such phrases earlier in use in American and British politics e.g. } \\
\text { according to Wikipedia 'Reaganomics refers to the economic policies promoted by } \\
\text { U.S. President Ronald Reagan during the 1980s'; and 'Thatcherism', the (a)nalysis } \\
\text { and definition of the political ideas, that shaped British Prime Minister Margaret } \\
\text { Thatcher's time in } 10 \text { Downing Street'. } \\
\text { In the second headline, the male dominated culture is depicted by using a popular } \\
\text { brand of soap/shaving cream called 'Imperial Lather'. It is in the context of the } \\
\text { constitution and centuries' long tradition of not having a female heir to the throne. }\end{array}$} \\
\hline March $19^{\text {th }}-25^{\text {th }}$ & $\begin{array}{l}\text { Japan's male only } \\
\text { emperor system, } \\
\text { Imperial Lather }\end{array}$ & \\
\hline
\end{tabular}




\section{REFERENCES}

[1] A Brief History of Nuclear Accidents Worldwide, Union of Concerned Scientists, consulted on 15 March 2016, http://www.ucsusa.org/nuclear-power-accidents/history-nuc lear-accidents\#.WFL5MPkrLIU, (Note: 33 serious incidents and accidents have been identified since the first recorded in 1952).

[2] Radiation Disaster Medicine : Perspective from the Fukushima Nuclear Accident, edited by Koichi Tangawa, Rethy Kieth Chhem, Springer International Publishing, Switzerland, 2014, p. 10

[3] Sweeny, Dave, Fukushima five years on, and the lessons we failed to learn, The Guardian, consulted on 15 December 2016 ,

http://www.theguardian.com/commentisfree/2016/mar/11/f unkushima-five-years-on-and-the-lessons-we-failed-to-lear n.

[4] Ronald, Eisler, Senior Scientist (retired) U.S. Geological Survey, The Fukushima 2011 Disaster, CRC Press, 2011, p.94.

[5] Japan's hydra-headed disaster, The Fallout, The Economist, 17 March 2011

[6] Ibid.

[7] Ibid.

[8] Normile, Dennis, Five Years after the meltdown, Is it safe to live near Fukushima? Science, The Time Magazine, 2 March 2016;

http://science.sciencemag.org/content/suppl/2011/05/18/sci ence.1206731.DC1

[9] Normile, Dennis, Five Years after the meltdown, is it safe to live near Fukushima? Science, The Time Magazine, 2 March 2016.

[10] Olson, David L., Dash Wu, Pesheng, Enterprise Risk Management, Second Edition, World Scientific Publishing Co. Pte. Ltd., Singapore, 2015, p.8.

[11] Ibid

[12] Radiation Disaster Medicine, edited by Koichi Tanigawa, Reithy Kieth Chhem, Springer International Publishing, Switzerland, 2014, p.32

[13] Sweeny, Dave, Fukushima five years on, and the lessons we failed to learn, The Guardian, consulted on 15 December 2016 ,

http://www.theguardian.com/commentisfree/2016/mar/11/f unkushima-five-years-on-and-the-lessons-we-failed-to-lear n.

[14] http://www.unfpa.org/resources/core-international-human-ri ghts-instruments\#sthash.QOVTEXaA.dpuf

[15] Nowak, Manfred, Introducing to the International Human rights Regime, Martinus Nijhoff Publishers, Leiden/Boston, 2003.

[16] Ibid.
[17] https://facultystaff.richmond.edu/ wgreen/Ecd4phases.htm, consulted on 28 March 2017.

[18] David Machin; Andrea Mayr, How to do Critical Discourse Analysis, Sage Publications, London, 2012

[19] Discourse Studies, A Multidisciplinary Introduction, Edited by Teun A. Van Dijk, Sage Publications Ltd. 2011

[20] David Machin; Andrea Mayr, How to do Critical Discourse Analysis, Sage Publications, London, 2012, p.59; George Lakoff; Mark Johnson, Metaphors We Live By, The University of Chicago Press, 2003, p.162.

[21] http://www.un.org/en/udhrbook/pdf/udhr_booklet_en_web. pdf

[22] The Fukushima Daiichi Accident Report by the Director General, International Atomic Energy Agency (IAEA) $\mathrm{GC}(59) / 14,2015$

[23] Briefing Nuclear Power, When the steam clears, The Economist 26 March 2011, pp. 70-72.

[24] Radiation Disaster Medicine, edited by Koichi Tanigawa, Reithy Kieth Chhem, Springer International Publishing, Switzerland, 2014, p.34

[25] The Fukushima Daiichi Accident Report by the Director General, International Atomic Energy Agency (IAEA) GC(59)/14, 2015

[26] Nuclear workers in Japan, Heroism and Humility, The Economist, October 27th 2012, pp.47-48

[27] Japan Five years on, the cleanup workers of Fukushima are still on the job, lightbox, The Time; Portraits of workers at the nuclear power plant in Okuma, Japan, taken on Feb. 23, 2016.

[28] Disaster in Japan, Come Back in ten years' time, The Economist, 26 March 2011, p. 55.

[29] Ibid.

[30] M. Morrey and P. Allen, The Role of Social and Psychological Factors in Radiation Protection After Accidents, Radiation Protection Dosimetry, Nuclear technology Publishing, Vol. 68, No. 3 / 4, pp.267-271 (1996).

[31] Ibid.

[32] Japan's anti-nuclear protests, The heat rises, The Economist, 21 July 2012, p. 46

[33] The dream that failed, The Economist, 14 March 2012, p. 15.

[34] Paolo Gardoni and Colleen Murphy, Nuclear energy, the capability approach, and the developing world, The Ethics of Nuclear Energy, Risk, Justice and Democracy in the post-Fukushima Era, edited by Behnam Taebi and Sabine Roeser, Cambridge University Press, 2015, pp.216-230.

[35] Can Japan's Anti-Nuclear Protesters Keep Its Reactors Shut Down? By Lucy Birmingham / Tokyo Wednesday, Sept. 28, 2011, (Courtesy The Time Magazine NewsFeed)

[36] Japan and free trade, Better late than never, The Economist, 23 March 2013, p. 52.

[37] The world Economy, from tsunamis to Typhoons, The 
Economist, 26 March 2011, pp. 73-74.

[38] Ibid.

[39] Japan's anti-nuclear protests, The heat rises, The Economist, 21 July 2012, p. 46

[40] Japan's Fiscal Mess, A pound of flesh, The Economist, 23 June 2012, pp. 54-55.

[41] Aftermath: How Japan Will Recover from the Quake, By Hannah Beech/Akaushi Sunday, Mar. 20, 2011, (Courtesy The Time Magazine NewsFeed).

[42] Briefing Japan's Catastrophe-Nature Strikes Back, The Economist, 19 March 2011, pp. 23-27.

[43] Lemieux, Anthony F., Chambers Melany, Georgia State University, The Sage Encyclopaedia of Cancer and Society, Second Edition, UK 2015, p.381.

[44] Disaster in Japan, Come Back in ten years' time, The Economist, 26 March 2011, p. 55.

[45] In June 2008, staff at the Federal Energy Regulatory Commission estimated that building a new 1,000 megawatt (MW) reactor could cost up to $\$ 7.5$ billion. http://www.uspirg.org/reports/usp/high-cost-nuclear-power

[46] The dream that failed, The Economist, March 14th 2012

[47] Ronald, Eisler, Senior Scientist (retired) U.S. Geological Survey, The Fukushima 2011 Disaster, CRC Press, 2011,

[48] Nuclear Power and Energy Policy, pp.195

[49] Pius Krüetli, Kjell Törnblom, Ivo wallimann-Helmer, and Michael Stauffacher, Distributive versus procedural justice in nuclear waste repository siting, The Ethics of Nuclear Energy, Risk, Justice and Democracy in post -Fukushima Era, pp.119-140

[50] Kzuya Nakayachi, Examining Public Trust in Risk-Managing Organizations After a Major Disaster, Risk Analysis Vol.33, No.1, 2015, pp.57-67.

[51] Briefing Japan's Catastrophe-Nature Strikes Back, The Economist, 19 March 2011, pp. 23-27.

[52] Fukushima Disaster: Impacts and Continuing Threats, A Factsheet from Physicians for Social Responsibility, Washington, USA, www.psr.org

[53] How to Drive Change, Carlos Ghosn, Chairman and CEO of Renault- Nissan Alliance,

http://content.time.com/time/magazine/article/0,9171,20794 76-2,00.html

[54] The Fallout, The Economist 19 March 2011, pp 13-14.

[55] http://www.iaea.org/newscenter/news/iaea-delivers-major-r eport-fukushima-accident-member-states Consulted on 15 May 2015.

[56] The Fukushima Daiichi Accident Report by the Director General, International Atomic Energy Agency (IAEA) GC(59)/14, 2015

[57] After Fukushima, Germany's Nuclear Utility Faces Losses, Layoffs, By Markus Balser / SÜDDEUTSCHE ZEITUNG / Worldcrunch Monday, Aug. 01, 2011, (Courtesy The Time Magazine NewsFeed).
[58] Huang et el, Effect of the Fukushima nuclear accident on the risk perception of residents near a nuclear power plant in China; PNAS, 3 December 2013, pp. 19742-19747, www.pnas.org/cgi/doi/10.1073/pnas.1313825110,

[59] http://en.wikipedia.org/International_reactions_to the_Fuk ushima_Daiich_nuclear_disaster consulted on 1st October 2015

[60] Nuclear Power in Japan, Start 'em up, The Economist, March 8th 2014. p. 45

[61] http://www.un.org/en/universal-declaration-human-rights/

[62] Pius Krüetli, Kjell Törnblom, Ivo wallimann-Helmer, and Michael Stauffacher, Distributive versus procedural justice in nuclear waste repository siting, The Ethics of Nuclear Energy, Risk, Justice and Democracy in post -Fukushima Era, pp. $119-140$

[63] http://www.ohchr.org/EN/ProfessionalInterest/Pages/CESC R.aspx

[64] Ibid.

[65] Mamun, M.M.A., Recent Fukushima nuclear detonation, Chernobyl nuclear fallout, three mile island nuclear accident and atomic bomb explosion - rethinking the effects of nuclear radiations over human health, International Journal of Radiation Research, Vol. 11, No.2, April 2013, pp.63-80.

[66] https://en.wikipedia.org/wiki/Occupational_safety_and_hea lth\#cite note- 6 consulted on 7 October 2016

[67] http://www.ohchr.org/EN/ProfessionalInterest/Pages/CESC R.aspx

[68] Ilina Cenevska 2016

[69] Japan Five years on, the cleanup workers of Fukushima are still on the job, lightbox, The Time; Portraits of workers at the nuclear power plant in Okuma, Japan, taken on Feb. 23, 2016.

[70] http://fra.europa.eu/en/charterpedia/article/37-environmenta 1-protection

[71] Gardoni, Paolo and Murphy, Colleen, Nuclear Energy, the capability approach, and the developing world, The Ethics of Nuclear Energy, Risk, Justice and Democracy in the post Fukushima Era, edited by Taebi, Behnam and Roeser Sabine, Cambridge University Press, 2015, pp.216-230. (quoted from Mileti 1999:232)

[72] Rebuilding Japan, Time Magazine, Monday July 04, 2011; (article: March 11 - Japan's Zero Hour, Yoichi Funabashi, Former Editor in Chief of the Asahi Shimbun).

[73] Paolo Gardoni and Colleen Murphy, Nuclear energy, the capability approach, and the developing world, The Ethics of Nuclear Energy, Risk, Justice and Democracy in the post-Fukushima Era, edited by Behnam Taebi and Sabine Roeser, Cambridge University Press, 2015, pp.216-230.

[74] Ibid.

[75] http://www.un.org/en/universal-declaration-human-rights/ consulted on 23 July 2017.

[76] Olson, David L., Dash Wu, Pesheng, Enterprise Risk Management, Second Edition, World Scientific Publishing Co. Pte. Ltd., Singapore, 2015, p.10. 
[77] Natural disasters, The rising cost of catastrophes, The Economist, 14 January 2012, p .11.

[78] Mamun, M.M.A., Recent Fukushima nuclear detonation, Chernobyl nuclear fallout, three mile island nuclear accident and atomic bomb explosion - rethinking the effects of nuclear radiations over human health, International Journal of Radiation Research, Vol. 11, No.2, April 2013, pp.63-80.

[79] Juliana Raupp, Strategizing Risk Communication, The Routledge Handbook of Strategic Communication, N.Y. 2015, pp.520-532

[80] Timothy F. Braun and Lisa M. Glidden, Understanding Energy and Energy Policy, Zed Book London, 2014, p. 34.

[81] http://www.claiminghumanrights.org/udhr_article_19.html

[82] Japanese Politics, Hair Shirts, The Economist, 24 March 2012, pp. 53-54.
[83] Olson, David L., Dash Wu, Pesheng, Enterprise Risk Management, Second Edition, World Scientific Publishing Co. Pte. Ltd., Singapore, 2015, p.10.

[84] Kzuya Nakayachi, Examining Public Trust in Risk-Managing Organizations After a Major Disaster, Risk Analysis Vol.33, No.1, 2015, pp.57-67.

[85] Baker K; Stoker G, Nuclear Power and Energy Policy, Palgrave Macmillan, London, 2015, pp.193

[86] Ibid. pp.195

[87] Japan's asylum laws, No entry, The Economist, 14 March 2015, p. 48.

[88] Disaster and demography in Japan, Generational warfare, The Economist, August 4th 2012, p. 45.

[89] Japanese Politics, Abe agonistes, The Economist, 12 March 2016, p.46 